\title{
NEW GRASSLAND ASSOCIATION TRISETO-CENTAUREETUM MACROPTILI ASS. NOVA IN SLOVENIA
}

\author{
Igor ZELNIK*
}

\begin{abstract}
The work describes the community of improved meadows that thrives on the elevated parts of alluvia and sometimes marshes, on the sites above the flooded areas. These stands were found and recorded in the subPannonian and pre-Dinaric areas of Slovenia. The relevés were compared with other similar communities from the alliance Arrhenatherion Koch 1926 as well as some of the ecological characteristics. A new association named Triseto-Centaureetum macroptili ass. nova is here proposed. It was classified into alliance Arrhenatherion and order Arrhenatheretalia R. Tx 1931. The characters of the order Molinietalia Koch 1926 are also common, which reflects the transitional environmental conditions of those sites. The association thrives on deposits, predominantly on levees, where the soil is permeable for water. The material from these meadows, which are mown once to twice a year, is used for fodder and not for litter, which confirms their classification.
\end{abstract}

Key words: Arrhenatherion, phytosociology, meadow vegetation, Slovenia.

\section{Izvleček}

Prispevek opisuje združbo intenzivno gojenih travnikov, ki uspeva na dvignjenih mestih aluvialnih nanosov in včasih močvirij, na rastiščih nad poplavljenimi predeli. Tovrstni sestoji so bili najdeni in popisani v subpanonskem in preddinarskem območju Slovenije. Vegetacijske popise, kot tudi nekatere ekološke značilnosti smo primerjali z drugimi podobnimi združbami iz zveze Arrhenatherion Koch 1926. Opisali smo novo travniško združbo z imenom Triseto-Centaureetum macroptili ass. nova. Asociacijo smo uvrstili v zvezo Arrhenatherion Koch 1926 in red Arrhenatheretalia R. Tx 1931. Pogoste so tudi značilnice reda Molinietalia Koch 1926, kar kaže na prehodne ekološke razmere teh rastišč. Asociacija uspeva na naplavinah, predvsem na nasipih, kjer so tla prepustna za vodo. Material iz teh travnikov, ki so košeni enkrat do dvakrat letno, uporabljajo za krmo in ne za steljo, kar potrjuje njihovo klasifikacijo.

Ključne besede: Arrhenatherion, fitocenologija, travniška vegetacija, Slovenija.

\section{INTRODUCTION}

Alliance Arrhenatherion Koch 1926 encompasses lowland to submontane, intensively managed meadows of Central Europe on wet to moderately dry sites, on slightly acid to neutral, mostly brown soils (Koch 1926). Most of these meadows are mown 2-6 times per year (Ellmauer \& Mucina 1993). The centre of distribution area of the alliance is in the southern regions of Central Europe. Although many associations have been described in Europe on the basis of regional floristic differences (Dierschke 2001), we still lack a clear overview of the alliance.

Géhu (2001) classified the more hygrophilous communities from this alliance into the suballiance Colchico autumnalis-Arrhenatherenion elatioris de Foucault 1989. This suballiance comprises mesohygrophilous meadows on alluvial and colluvial soil, which are situated next to the lower lying inundated and wet meadows of the order Potentillo-Polygonetalia R.Tx. 1947 and Molinietalia Koch 1926, respectively.

* Institute of Biology, Scientific Research Centre of the Slovenian Academy of Sciences and Arts, Novi trg 2, SI-1000 Ljubljana, Slovenia; fax: +386-1-425-7797; e-mail: izelnik@zrc-sazu.si. 
In the neighbouring countries, the meadow vegetation from the alliance Arrhenatherion has been studied by numerous researchers. In Croatia, the vegetation of lowland meadows was studied first by Horvatić $(1930,1958)$ and later also by Ilijanić \& Šegulja (1983), Stančić (2000) and Trinajstić (2000, 2002). In Italy, this vegetation was studied by Poldini (1989) and Poldini \& Oriolo (1994). Meadows of lowland regions in Austria were studied by Eggler (1958, 1959), Kuyper et al. (1978), Ellmauer (1994), Steinbuch (1995), Lichtenecker et al. (2003). An overview of the communities of the alliance Arrhenatherion in Austria is given in Ellmauer \& Mucina (1993). In Hungary, the meadows from the alliance Arrhenatherion were studied by Soó (1968) and Lájer (1998, 2002). A survey of these communities for the entire country can be found in Borhidi (2003).

In Slovakia, these meadows were studied by Špániková (1971, 1982), Zlinská \& Kubalová (2001). The meadows of the alliance Arrhenatherion in the southern and eastern part of the Czech Republic were studied by Blažková (1973) and Vicherek et al. (2000). A survey of the communities in the Czech Republic is available in Kučera \& Šumberová (2001). Publications dealing with grassland vegetation and ecology in Germany are Dierschke (1990, 1995) and Dierschke \& Briemle (2002), among others. A survey of these communities for southern Germany and for entire country is published in Oberdorfer (1993) and/or Pott (1995).

Newer publications, which are more or less founded on statistical processing of relevés in the literature and which present a survey of alliances of the associations and meadow communities in this region, are Havlová et al. (2004), Botta-Dukát (2004) and Botta-Dukát et al. (2005). These contributions do not give solutions at the level of associations, which are often equivalent and have been treated separately in different countries.

The first relevés of meadow vegetation in Slovenia were published by Aichinger (1933), who had made relevés of the community Arrhenatheretum elatioris Br.-Bl. 1919 in the Karavanke mountains. The vegetation of such meadows in Slovenia was systematically first studied by Horvatić (1939), who compared it with the Croatian ones. He mentioned also the demarcation line between the alliances $\mathrm{Mo}$ linion Koch 1926 and Deschampsion Horvatić 1930, with which he connects demarcation between the syntaxa Arrhenatheretum medioeuropaeum and A. orientale, as well as the particularity of the Krško basin within Slovenia. Horvatić \& Tomažič (1941) stud- ied the meadow vegetation of the order Arrhenatheretalia in the lowland belt of Slovenia.

Before the division of the community or macroassociation Arrhenatheretum elatioris, its thriving in Slovenia was documented by: Ilijanić (1979) on Lake Cerknica, Seliškar (1986) on the Ljubljana moor, Poldini (1989) on Karst and Brkini, Čarni et al. (1992) in Prekmurje.

In Slovenia, several associations of the alliance Arrhenatherion thrive on intensively managed meadows. Čarni et al. (1992) documented the thriving of the community Bromo-Cynosuretum cristati Horvatić (1930) 1958 in Prekmurje. The central association of intensively managed Central-European meadows Pastinaco-Arrhenatheretum Passarge 1964 is documented in Čarni (2001), namely in Prekmurje. Čarni (2001) also mentions the thriving of the association Ranunculo bulbosi-Arrhenatheretum Ellmauer 1993 and two, more hygrophilous associations Ranunculo-Alopecuretum pratensis (Eggler 1933) Ellmauer 1993 and Bromo-Cynosuretum cristati. In Jovsi, Seliškar (1993) documented the association Bromo-Cynosuretum on wetter, and Ononido-Arrhenatheretum elatioris (Tomažič \& Horvatić 1941) Ilijanić \& Šegulja 1983 on drier sites. In the last several years, more extensive studies of meadows in Slovenia have been conducted (Zelnik 2003, 2005), with which we determined the uniqueness of floristic composition of the studied stands. This enabled us to distinguish them easily from the other meadow communities studied and at the same time to treat them as a new syntaxon during the very course of our research.

\section{MATERIAL AND METHODS}

\subsection{Research area}

The meadows were investigated across the eastern half of the state (Fig. 2), in the continental part of Slovenia from the central part to the southeast and northeast, respectively (from $45^{\circ} 40^{\prime} \mathrm{N}, 14^{\circ} 10^{\prime} \mathrm{E}$ to $46^{\circ} 50^{\prime} \mathrm{N}, 16^{\circ} 20^{\prime} \mathrm{E}$ ). The researched area is classified into pre-Dinaric and sub-Pannonian phytogeographic regions (Wraber 1969). There is a strong gradient in annual precipitation from the $\mathrm{W}$ to $\mathrm{NE}$ part of the studied area. In the western part the climate is most humid with an annual precipitation of $1250 \mathrm{~mm}$, but in the NE part, the annual precipitation is $900 \mathrm{~mm}$ (Zupančič 1995). The gradient in mean annual temperature is much weaker, but 
it increases in the same direction as the precipitation amount decreases. There is a slight altitudinal gradient, as some plots can be found at about 138 $\mathrm{m}$ and others at $323 \mathrm{~m}$ a.s.l..

\subsection{Vegetation analysis}

Grassland vegetation was investigated according to the standard Central European method (BraunBlanquet 1964; Westhoff \& van der Maarel 1973). The cover-abundance values were transformed according to van der Maarel (1979). Vegetation relevés were made in 2001-2004, in May and June. The size of plots varies from 12 to $24 \mathrm{~m}^{2}$ due to the micro-topography. Nomenclature of ferns and flowering plants follows Ehrendorfer et al. (1973), with the exception of species Centaurea macroptilon Borb. and Centaurea carniolica Host. Plant taxa are classified into syntaxa according to Ellmauer \& Mucina (1993), Oberdorfer (1994) as well as local studies (Horvatić 1930). Nomenclature of syntaxa follows Ellmauer \& Mucina (1993) and local studies Zelnik (2005), Ilijanić \& Šegulja 1983. Nomenclature of the new syntaxa is in accordance with the code of Weber et al. (2000).

Relevés of various similar hygrophilous and mesophilous associations of the alliance Arrhenatherion from Slovenia, Croatia and Italy were subjected to multivariate analyses. The PCA was carried out on the base of 113 relevés using the computer program Canoco 4.02 (ter Braak \& Šmilauer 2002). Groups of relevés from synthetic tables were compared with the program SYN-TAX (Podani 2001) where PCoA was performed. In order to avoid misleading results in multivariate analyses due to incorrect and/or different levels of determination of the taxa Centaurea macroptilon, Centaurea jacea var. pectinata, Centaurea jacea, Centaurea sp. we united them into the taxon Centaurea jacea agg.

\subsection{Soil sampling and laboratory methods}

The soil samples were taken from the depth of $0-15 \mathrm{~cm}$ on plots, where relevés had been done before. The samples were taken in years 2001-2004, always in November to make results comparable. Composite soil samples were analysed at the Centre for Soil and Environmental Sciences of the Biotechnical Faculty in Ljubljana. The samples were treated in accordance with ISO 11464 and the following characteristics were measured in accord- ance with standard methods: $\mathrm{pH}\left(\mathrm{CaCl}_{2}\right)$ according to ISO 10390; organic carbon was determined in accordance with the ISO 14235 - modified Walkley-Black method; total nitrogen content $\left(\mathrm{N}_{\mathrm{t}}\right)$ according to the modified Kjeldahl method (ISO 11261); available phosphorus (P) and potassium (K) were determined with methods suggested by Hoffman, using the ammonium-lactate extraction; exchangeable cations $\left(\mathrm{Ca}^{2+}, \mathrm{Mg}^{2+}, \mathrm{K}^{+}, \mathrm{Na}^{+}\right)$ were analysed by atomic absorption spectrophotometry, while $\mathrm{H}^{+}$was determined using the titration method.

\section{RESULTS AND DISCUSSION}

\subsection{Triseto-Centaureetum macroptili ass. nova hoc loco (Holotypus: Table 1/relevé 5)}

The community thrives on less wet areas on wetland plains, often along streams and smaller lowslope rivers, on elevated parts where the water had deposited the coarsest particles and where the most structured and permeable soil developed. These stands are found also further from streams, e.g. on marshy sites on Plio-Quaternary sediments, which are slightly elevated above the flooded areas. The only time the water here stagnates on the surface is at the time of the highest water level, after which it withdraws in a few days. The water regime is similar to that in the community Bromo-Cynosuretum cristati, although the soil is not as wet, nor fertile enough to allow growth of this community. This is presented also in the distribution of the relevés in the PCA ordination (Fig. 1), where the x-axis represents the decreasing moisture gradient while the y-axis represents decreasing nutrient gradient, which confirms the above mentioned differences between associations Triseto-Centaureetum and Bromo-Cynosuretum.

This is the most common meadow community on clayey and loamy alluvial deposits and Plio-Quaternary sediments in the studied area. More often than not, the soil is base-poor from the very beginning, whereas in places the soil has also been impoverished due to long-term human activities.

The community is entirely different from the vegetation of inundated meadows of the order $\mathrm{Po}^{-}$ tentillo-Polygonetalia which grows on regularly inundated stream banks, although it occurs also along streams, but on sites which are only exceptionally flooded. 


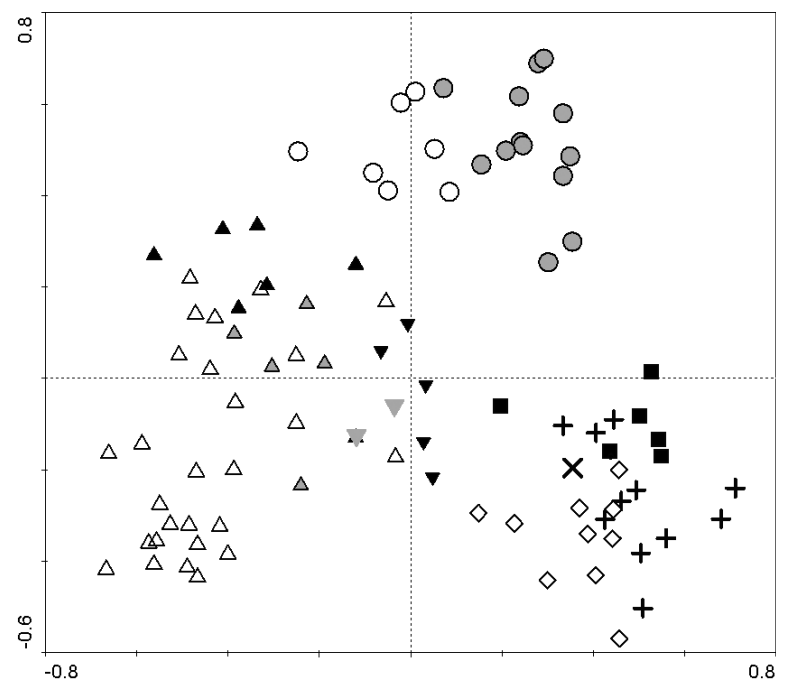

Figure 1: PCA ordination of the individual relevés of the associations: Bromo-Cynosuretum cristati, Filipendulo-Arrhenatheretum, Centaureo carniolici-Arrhenatheretum, PastinacoArrhenatheretum, Ononido-Arrhenatheretum and TrisetoCentaureetum macroptili:

Slika 1: PCA ordinacija posameznih popisov asociacij Bromo-Cynosuretum cristati, Filipendulo-Arrhenatheretum, Centaureo carniolici-Arrhenatheretum, Pastinaco-Arrhenatheretum, Ononido-Arrhenatheretum in Triseto-Centaureetum macroptili:

A - Zelnik (2005): tab. 17 / 1-7 - Bromo-Cynosuretum cristati;

$\triangle$ - Horvatić (1930): tab. 6 / 1-28-Bromo-Cynosuretum cristati;

V-Čarni (2001); tab. 1 / 27-31 - Bromo-Cynosuretum cristati;

$\triangle$ - Seliškar (1993): tab. 1/ 23-26 - Bromo-Cynosuretum cristati;

V - Čarni et al. (1992); tab. 2 / 6-7 - Bromo-Cynosuretum cristati;

- Trinajstić (2002); tab. 1 / 1-6 - Filipendulo-Arrhenatheretum;

+ - Poldini \& Oriolo (1994); tab. 1/ 1-12 - Centaureo carniolici-Arrhenatheretum;

$\diamond$ - Čarni (2001); tab. 1 / 8-17-Pastinaco-Arrhenatheretum;

x - Seliškar (1993): tab. 1/ 27 - Ononido-Arrhenatheretum;

O- Zelnik (hoc loco); tab. 1/1-13 - Triseto-Centaureetum macroptili avenuletosum pubescentis;

O-Zelnik (hoc loco); tab. 1 / 14-20 - Triseto-Centaureetum macroptili potentilletosum repentis.

\subsection{Character and differential species and floristic composition (Table 1)}

Local character species of the association are: Centaurea macroptilon (dominant), Trisetum flavescens, Daucus carota.

Character species of the alliance Arrhenatherion that grow within these stands: Trisetum flavescens, Arrhenatherum elatius, Campanula patula, Knautia arvensis, Pimpinella major, Crepis biennis. In some stands these characters are poorly represented, this being the consequence of the low total number of the species defined as characteristic for Arrhenatherion. There are also characters of the related alliance Cynosurion, but since it represents pastures and trampled meadows, our stands cannot be classified into the mentioned alliance.

Numerous other character species of the order Arrhenatheretalia grow within these stands: Poa pratensis, Rumex acetosa, Ajuga reptans, Daucus carota, Cerastium holosteoides, Cynosurus cristatus, Lotus corniculatus, Trifolium patens, Prunella vulgaris, Achillea millefolium, Taraxacum officinale agg., Leucanthemum ircutianum, Stellaria graminea, Trifolium dubium, Leontodon autumnalis, Stellaria graminea, Avenula pubescens, Trifolium dubium, Lolium perenne, Veronica serpyllifolia, Tragopogon orientalis, Trifolium repens, Hypochaeris radicata, Rhinanthus minor, Phleum pratense agg.

Differential species from the association BromoCynosuretum cristati are (except for the last one) the character species of the class Calluno-Ulicetea: Potentilla erecta, Danthonia decumbens, Thymus pulegioides, Juncus conglomeratus.

The association is characterized by dominance or co-dominance of the species Centaurea macroptilon and Trisetum flavescens. Occasionally on wetter sites Holcus lanatus can have higher coverage. The coverage also changes slightly between seasons. On several sites we have noticed the alternation of dominance between Centaurea macroptilon and Trisetum flavescens through the years. Although many species of the order Arrhenatheretalia thrive here which is the reason why the association is classified into this order there are also numerous species of oligotrophic sites, namely the character species of the class Calluno-Ulicetea (Carex pallescens, Luzula campestris agg., Potentilla erecta, Festuca filiformis, Danthonia decumbens, Thymus pulegioides, Carex leporina, Viola canina, Hieracium umbellatum, H. lactucella, Nardus stricta) and character species of the class Festuco-Brometea (Galium verum, Briza media, Filipendula vulgaris, Carex flacca, Allium carinatum, Campanula glomerata, Ranunculus bulbosus). 
As already mentioned, these species floristically differentiate this association from the association Bromo-Cynosuretum cristati (Fig. 1). These characteristics are reflected also in the distribution of the relevés in PCA ordination (Fig. 1), since the y-axis represents the decreasing nutrient gradient. Apart from that, there are not sufficient character species of the above-mentioned community in the stands studied, or they have only very low frequency and coverage. On the other hand, species like Anthoxanthum odoratum and Festuca rubra agg. have high frequency and coverage.

Many species of the order Molinietalia (Lychnis flos-cuculi, Centaurea carniolica, Betonica officinalis, Juncus conglomeratus, Carex tomentosa, Cardamine pratensis agg., Deschampsia cespitosa, Selinum carvifolia, Sanguisorba officinalis, Colchicum autumnale, Bromus racemosus, Molinia caerulea, Myosotis scorpioides, Ophioglossum vulgatum, Vicia tetrasperma, Succisella inflexa) indicate similar ecological conditions to those of the wet meadows. These stands are mostly in contact with the stands of different communities from the alliance Deschampsion or Molinion. Another species, a character of the alliance Deschampsion, should be mentioned here - Centaurea carniolica, which is also common in this association and has sometimes even higher coverage than C. macroptilon. The species often grows on intermittently wet soil.

\subsection{Results of the analyses of ecological factors}

Of all the wet meadow and contact communities studied (see Zelnik 2005), this one thrives on the least wet sites. During the course of our research, these stands were never inundated during the vegetation seasons. Usually, the soil was saturated with water only for one week in spring.

The soil on these sites is acid, with $\mathrm{pH}$ value of cca 5. The base-cation content ( $\mathrm{S}$ ) is very low, especially of $\mathrm{Ca}^{2+}$ (10.9 meq). A lower value was measured only in acidophilous communities from the alliance Molinion (Zelnik 2005). The lowest is also the content of plant-available $\mathrm{K}$.

The proportion of clay in the soil is the lowest among the collected samples $(\sim 20 \%)$ (Zelnik 2005). The soil is more permeable than in the communities from the order Molinietalia and some other hygrophilous communities from the alliance Arrhenatherion. Water permeable and aerated soils, as well as slightly elevated sites, enable the dominance of the species from the alliance Arrhenatheri- on and order Arrhenatheretalia. Also significant here is the intensity of use, as these meadows are mowed in June and occasionally also in September, which inhibits the growth of competitively stronger, tallgrowing species.

Regular mowing and relatively dry sites obstruct accumulation of organic matter in the soil. Mineralization and circulation of matter is the fastest here, so the proportion of organic matter in the soil ( $4.7 \%$ org. C) is among the lowest (Zelnik 2005). This is also the reason for the low content of nutrients in comparison with others, although a community classified into the alliance Arrhenatherion grows here.

\subsection{Division of the association in the study area}

With consideration of the wetness of the sites, we classified the relevés into two subassociations (Fig. 1): avenuletosum pubescentis and potentilletosum repentis.

\section{Triseto-Centaureetum macroptili avenuletosum pubes-} centis subass. nova hoc loco

(Table 1, relevés 1-13; holotypus: Table 1/relevé 6)

Differential species of the subassociation are: Achillea millefolium, Dactylis glomerata, Filipendula vulgaris, Avenula pubescens, Tragopogon orientalis.

There are more species of the class Festuco-Brometea than in the subassociation potentilletosum, Filipendula vulgaris is even a character species of this subassociation, while another three characters are from the order Arrhenatheretalia. Characteristic for this subassociation, which grows on less wet sites that are never flooded, is also the growth of the characters of the class Calluno-Ulicetea (Festuca filiformis, Viola canina, Hieracium umbellatum, Nardus stricta). The less hygrophilous character is evident also from the ordination (Fig. 1), where these relevés are distributed in the direction of decreasing moisture gradient and in the direction of the mesophilous associations with dominant species Arrhenatherum elatius (e.g. Pastinaco-Arrhenatheretum), respectively. The outstanding number of the species of wet and oligotrophic sites (Molinietalia, Scheuchzerio-Caricetea fuscae) in relevé 2 occurred because this meadow is surrounded by wet meadow and marsh vegetation and these species occur there coincidently. Besides, the cover value is the lowest here $(90 \%)$, which has enabled the survival of the mentioned less competitive species. 
Triseto-Centaureetum macroptili potentilletosum repentis subass. nova hoc loco

(Table 1, relevés 14-20; holotypus: Table 1/relevé 14)

Differential species of the subassociation are:

Leontodon autumnalis, Potentilla reptans, Lysimachia nummularia, Juncus conglomeratus.

The subassociation grows on slightly wetter sites than the previous; such sites can be inundated for several days at the time of the highest water level. This is indicated also by the differential species, which come from the order Potentillo-Polygonetalia and alliance Molinion. Floristically, the subassociation potentilletosum repentis also differs from the former by the higher number and/or frequency of the species of the class Phragmiti-Magnocaricetea (Carex vulpina, Galium palustre, Carex acuta, Lycopus europaeus), and by the absence of many species from classes Festuco-Brometea and Calluno-Ulicetea.

\subsection{Distribution in Slovenia}

Stands of this association were found and recorded only in the sub-Pannonian and pre-Dinaric phytogeographical region.

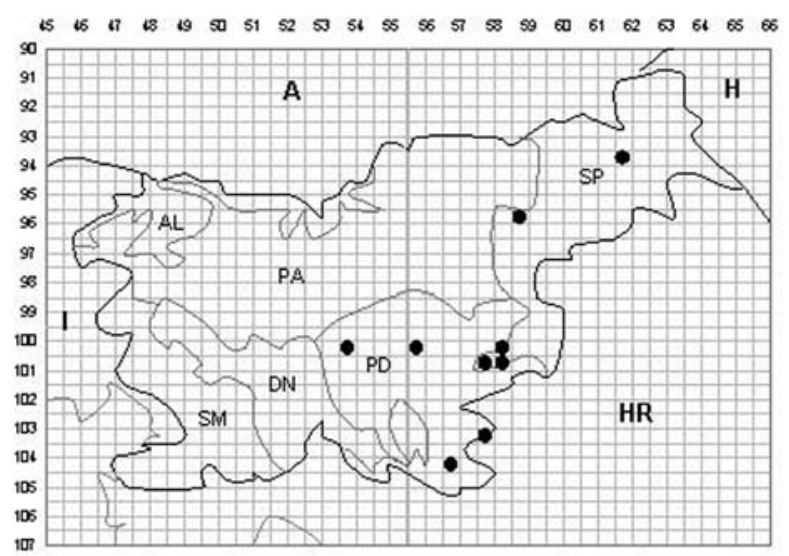

Figure 2: Localities of relevés from the association TrisetoCentaureetum macroptili in the studied area.

Slika 2: Lokalitete popisov asociacije Triseto-Centaureetum macroptili na preučevanem območju.

The distribution area of the association is limited by the distribution of C. macroptilon, as this dominant and character species becomes rarer towards the west of Slovenia and does not grow at all in Friuli (Italy). Its frequency decreases also towards $\mathrm{NE}$ and the species is already very rare in Prekmurje (Zelnik 2005), where the studied association can be found only on the western margins (along the
Mura river). The association is presumably regionally distributed. There is a high probability that the association thrives in central Croatia, in the Sotla, Kolpa and Sava river basins, as most of the localities of the relevés (Bela krajina, Krško-Brežice plain) are very close to the Croatian border.

\subsection{Syntaxonomical position of the association}

Together with other hygrophilous associations from the alliance Arrhenatherion, such as Bromo-Cynosuretum cristati, Ranunculo-Alopecuretum pratensis, Festucetum pratensis Soó 1958, the association Triseto-Centaureetum macroptili ass. nova can be classified into the group of associations that corresponds to the suballiance Colchico autumnalis-Arrhenatherenion elatioris. These communities, mostly contact communities with those of the order Molinietalia, are classified into the aforementioned suballiance also by Géhu (2001). Characteristic for these communities growing in Slovenia is that they grow on wetter sites than the communities with the dominant Arrhenatherum elatius. The studied association was compared to the following associations on the base of the relevé groups:

1-5-Bromo-Cynosuretum cristati,

1: Zelnik (2005: tab. 17)

2: Horvatić (1930: tab. 6)

3: Čarni (2001: tab. 1)

4: Seliškar (1993)

5: Čarni et al. (1992: tab. 2)

6 - Triseto-Centaureetum macroptili, Zelnik hoc loco: tab. 1

7 - Filipendulo-Arrhenatheretum, Trinajstić (2002: tab. 1)

8 - Centaureo carniolici-Arrhenatheretum, Poldini \& Oriolo (1994: tab. 1)

9 - Pastinaco-Arrhenatheretum, Čarni (2001: tab. 1)

10 - Ranunculo repentis-Alopecuretum pratensis, Čarni (2001: tab. 1)

11 - Holcus lanatus community, Čarni (2001: tab. 1)

12 - Ononido-Arrhenatheretum, Seliškar (1993)

Considering its ecology, distribution and floristic composition, this association resembles the association Bromo-Cynosuretum cristati, but their relevés are clearly separated (Figs. 1 \& 3). Regarding its floristic composition, the association is similar also to the association Centaureo carniolicae-Arrhenatheretum 
elatioris (Oberdorfer 1964) Poldini \& Oriolo 1994, which grows in the lowland and montane belt of Friuli, on moderately wet to moderately dry, and moderately acid to neutral soil (Poldini \& Oriolo 1994). Within the association, the authors mention as differential the species Centaurea carniolica and its hybrids. The third association with which we determined relative similarity is Filipendulo-Arrhenatheretum (Figs. $1 \& 3$ ), which is the most hygrophilous association with dominant oat grass. In certain localities in the field we even noticed an intermediate position of the described association along the moisture gradient between the higher lying stands of the community Filipendulo-Arrhenatheretum and lower lying stands from the community Bromo-Cynosuretum cristati, which is evident also from Figure 3.

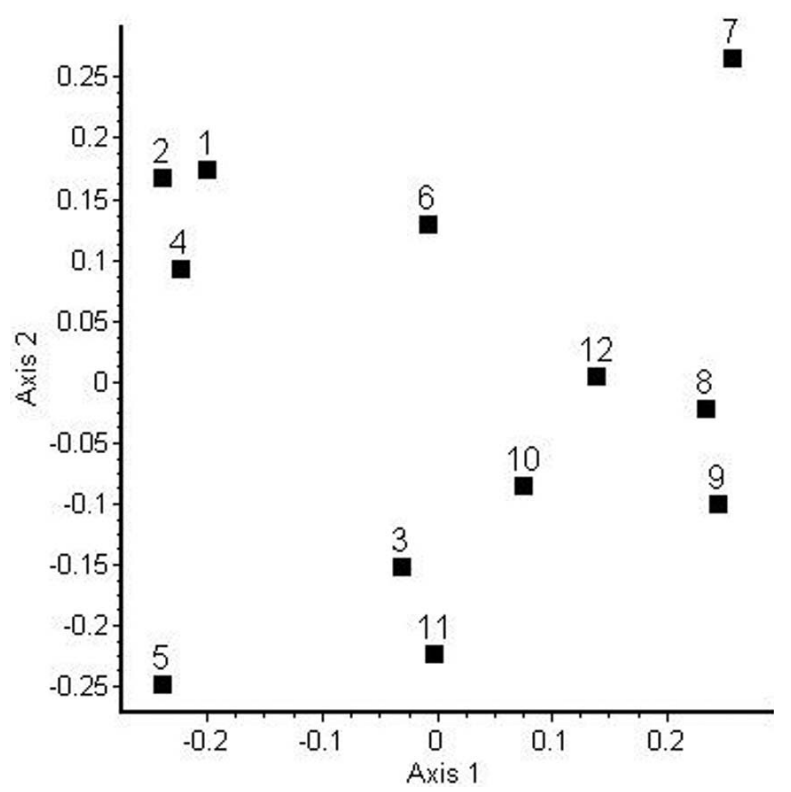

Figure 3: PCoA ordination of groups of relevés of the associations from the alliance Arrhenatherion (PCoA, complement of the similarity coefficient).

Slika 3: PCoA ordinacija skupin popisov asociacij zveze Arrhenatherion (PCoA, komplement koeficienta podobnosti).

\section{CONCLUSION}

The association described is an important meadow community of eastern Slovenia - the study area is situated on the western fringe of the Pannonian region. It is the most common meadow community on clayey and loamy alluvial deposits and Plio-Quaternary sediments. The soil is mostly base-poor from the very beginning, but in some places it is impoverished because of long-term human activities. Such vegetation type fills the gap between the intensively grown, highly productive meadows with prevailing oat grass and extensive wet meadows. Its transitional character is the result of ecological factors, such as water regime which is similar to wet meadows (Molinietalia) and which prevents intensive use of these meadows. On the other hand, however, the sites are still dry enough to allow dominance of mesophilous species. Early first mowing also contributes to that, as it prevents growth of stress-tolerant competitive species characteristic for wetlands. With regard to their floristic composition and by applying multivariate analyses, we classified these stands in the following way:

\section{Molinio-Arrhenatheretea R.Tx. 1937 em. R.Tx. 1970 \\ Arrhenatheretalia R. Tx 1931 \\ Arrhenatherion Koch 1926 \\ Triseto-Centaureetum macroptili ass. nova}

The association is presumably regionally distributed. Its dominant and character species C. macroptilon gets rarer towards the west of Slovenia and does not grow at all in Friuli. Its frequency decreases also towards NE and the species is already very rare in Prekmurje (Zelnik 2005), where the studied association can be found only on the western fringes (along the Mura river). There is a high probability that the association grows in central Croatia in the Sotla, Kolpa and Sava river basins.

\section{ACKNOWLEDGEMENTS}

I would like to thank Doc. Dr. Andraž Čarni and Prof. Dr. Andrej Martinčič for help in preparation of this paper, which originated as a part of the dissertation. Thanks to Prof. Dr. Franc Lobnik and others from the Centre for Soil and Environmental Sciences (University of Ljubljana) for performing the soil analyses. For designing the distribution map I am grateful to Marjan Jarnjak.

\section{LITERATURE}

Aichinger, E. 1933: Vegetationskunde der Karawanken. Pflanzensoziologie 2, G.Fischer, Jena, 314 pp.

Blažková, D. 1973: Pflanzensoziologische Studie über die Wiesen der Südböhmischen Becken. Academia, Praha, 170 pp. 
Borhidi, A. 2003: Magyarország növénytársulásai. Akadémiai kiadó, Budapest, 587 pp.

Botta-Dukát, Z. 2004: A Magyarországi mocsárrétek cönológiai irodalmának áttekintése és szüntaxonómiai revíziója. Kanitzia 12: 43-73.

Botta-Dukát, Z., Chytrý, M., Hájková, P. \& Havlová, M. 2005: Vegetation of lowland wet meadows along a climatic continentality gradient in Central Europe. Preslia 77: 89-111.

Braun-Blanquet, J. 1964: Pflanzensoziologie. Grundzüge der Vegetationskunde Springer, Wien, $865 \mathrm{pp}$.

Čarni, A., Seliškar, A. \& Zupančič, M. 1992: Pregled gozdne in travniške vegetacije na Goričkem v Prekmurju (Slovenija). Ljubljana, Znanstv. Rev. 1 (1992): 23-43.

Čarni, A. 2001: Vegetation of cultivated grasslands in the Goričko region (NE Slovenia). Acta Biologica Slovenica 44 (4): 13-27.

Dierschke, H. 1990: Syntaxonomische Gliederung des Wirtschaftsgrünlandes und verwandter Gesellschaften (M-A) in Westdeutschland. Berichten der Reinhold Tüxen-Gesellschaft 2: 83-89.

Dierschke, H. 1995: Syntaxonomical Survey of Molinio-Arrhenatheretea in Central Europe. Colloques Phytosociologiques (Bailleul) 23: 387-399.

Dierschke, H. 2001: Short survey of Arrhenatheretalia Grassland in Germany. Annali di botanica 1 (1): 7-15.

Dierschke, H. \& Briemle, G. 2002: Kulturgrasland: Wiesen, Weiden und verwandte Staudenfluren. E. Ulmer, Stuttgart, 239 pp.

Eggler, J. 1958: Wiesen und Wälder des Sasstales in Steiermark. Mitteilungen des Naturwissen. Vereins Steiermark 88: 23-54.

Eggler, J. 1959: Wiesen und Wälder im oststeirischburgenlandische Grenzgebiet. Mitteilungen des Naturwissen. Vereins Steiermark 89: 5-34.

Ehrendorfer, F. 1973: Liste der Gefässpflanzen Mitteleuropas. Stuttgart, G. Fischer, 318 pp.

Ellmauer, T. \& Mucina, L. 1993: Molinio-Arrhenatheretea. In: Die Pflanzengesellschaften Österreichs, Teil 1. Mucina L., Grabherr G., Ellmauer T. (eds.): Fischer, Jena, Stuttgart, pp. 297-401.

Ellmauer, T. 1994: Syntaxonomie der Frischwiesen (Molinio-Arrhenatheretea p.p.) in Österreich. Tüxenia 14: 151-168.

Géhu, J.-M. 2001: Synsystematique des prairies de France. Annali di botanica 1 (1): 15-30.

Havlová, M., Chytrý, M.\& Tichý, L. 2004: Diversity of hay meadows in the Czech Republic: major types and environmental gradients. Phytocoenologia 34: 551-567.
Horvatić, S. 1930: Soziologische Einheiten der Niederungswiesen in Kroatien und Slavonien. Acta Botanica inst. Bot. uni. Zagreb 5: 57-118.

Horvatić, S. 1939: Splošna primerjava vegetacije nižinskih travnikov Slovenije z ono iz Hrvatske in Slavonije. Zbornik prirodoslovnega društva 1: 40-43.

Horvatić, S. 1958: Geographisch-typologische Gliederung der Niederungs-Wiesen und - Weiden Kroatiens. Angewandte pflanzensociologie 15: 63-73.

Horvatić, S. \& Tomažič, G. 1941: Travniška vegetacija reda Arrhenatheretalia v nižinskem pasu Slovenije. Zbornik prirodoslovnega društva 2: 68-75.

Ilijanić, L. 1979: Die Vegetationsverhältnisse des Sees von Cerknica, Sumpf-, Moor- und WiesenVegetation. Acta carsologica 8: 166-200.

Ilijanić, L. \& Š́gulja, N. 1983: Phytozönologische und ökologische Untersuchungen der Glatthaferwiesen in der Podravina (Nordkroatien). Acta Bot. Croat. 42: 63-82.

Koch, W. 1926: Die Vegetationseinheiten der Linthebene. Jahrb. St. - Gall. Naturwiss. Ges. 61: 1-144.

Kučera, T. \& Šumberová, K. 2001: Louky a pastviny. In: Chytrý M., Kučera T., Kočí M. (eds.): Katalog biotopů České republiky. Agentura ochrany přírody a krajiny ČR, Praha, pp. 109-125.

Kuyper, T. W., Leeuwenberg, H. \& Hübl, E. 1978: Vegetationskundliche Studie an Feucht-, Moorund Streuwiesen im Burgenland und östlichen Niederösterreich. Linzer biol. Beitr. 10(2): 231-321.

Lájer, K. 1998: Újabb adatok Belső-Somogy florájanak es vegetáciojának ismerétehez. Somogyi Muzeomok Közleményei 13: 217-239.

Lájer, K. 2002: Floristical and coenological studies on meadows of the Somogy county valley of river Drava. Kitaibelia 7: 187-205.

Lichtenecker, A., Bassler, G. \& Karrer, G. 2003: Klassifikation der Wirtschaftswiesen (Arrhenatheretalia) im Zentralraum des Waldviertels. Wiss. Mitt. Niederösterr. Landesmuseum 15: 49-84.

Oberdorfer, E. 1993: Süddeutsche Pflanzengesellschaften. Teil 3: Wirtschaftswiesen und Unkrautgesellschaften, 3. Auflage. Fischer, Jena, Stuttgart, $455 \mathrm{pp}$.

Oberdorfer, E. 1994: Pflanzensoziologische Exkursionsflora. 7. Auflage, E. Ulmer, Stuttgart, 1050 pp.

Podani, J. 2001: SYN-TAX-2000. Computer Programs for Data Analysis in Ecology and Systematics. Scientia Publishing, Budapest, 53 pp. 
Poldini, L. 1989: La vegetazione del Carso Isontino e Triestino. Edizioni LINT, Trieste, 313 pp.

Poldini, L. \& Oriolo, G. 1994: La vegetazione dei prati da sfalcio e dei pascoli intensivi (Arrhenatheretalia e Poo-Trisetetalia) in Friuli (NE Italia). Studia Geobotanica 14 (1): 3-48.

Pott, R. 1995: Die Pflanzengesellschaften Deutschlands. 2. Auflage, Ulmer, Stuttgart, 622 pp.

Seliškar, A. 1986: Vodna, močvirna in traviščna vegetacija Ljubljanskega barja (vzhodni del). Scopolia 10: 1-43.

Seliškar, A. 1993: Vegetacija poplavnega območja Jovsi ob reki Sotli (Brežice, Slovenija). Hladnikia 1: 35-46.

Soó, R. 1968: Neue Übersicht der höheren zönologischen Einheiten der ungarischen Vegetation. Acta Bot. Acad. Sci. Hung. 14 (3D4): 385-394.

Stančić, Z. 2000: Meadows of the class MolinioArrhenatheretea in the northwest Croatia. Doctoral dissertation, University of Zagreb, Faculty of natural sciences and mathematics, Biol. Department, $244 \mathrm{pp}$.

Steinbuch, E. 1995: Wiesen und Weiden der Ost-, Süd- und Weststeiermark. Dissertationes Botanicae 253: $184 \mathrm{pp}$.

Špániková, A. 1971: Fytocenologicka študia luk juhozapadnej časti Košickej kotliny. Biologicke prace, Slovenska akademia vied 17 (2): $1-105$.

Špániková, A. 1982: Die Rasen- und Krautgesellschaften der Wiesen und Weiden im PopradFlussgebiet. In: Špániková, A. \& Zaliberova, M. (eds.): Die Vegetation des Poprad-Flussgebietes. Vegetacia ČSSR, Veda, Bratislava, pp. 25-132.

ter Braak, C.J.F. \& Šmilauer, P. 2002: CANOCO reference manual and CanoDraw for Windows user 's guide. Software for Canonical Community Ordination (version 4.5). Microcomputer Power, Ithaca, $500 \mathrm{pp}$.
Trinajstić, I. 2002: Livade rane pahovke s gomoljastom končarom - as. Filipendulo vulgaris-Arrhenatheretum Hundt \& Hübl (Arrhenatherion) u Hrvatskoj. Agronomski glasnik 3-4: 125-135.

van der Maarel, E. 1979: Transformation of Coverabundance values in Phytosociology and its effects on Community Similarity. Vegetatio 39: $97-114$.

Vicherek, J., Antonín, V., Danihelka, J., Grulich, V., Gruna, B., Hradilek, Z., Řehořek, V., Šumberová, K., Vampola, P. \& Vágner, A. 2000: Flora a vegetace na soutoku Moravy a Dyje. Vegetace. Masarykova universita v Brne, Brno, pp. 181-290.

Weber, H.E., Moravec, J. \& Theurillat, J.-P. 2000: International Code of Phytosociological Nomenclature. 3rd edition. J. Vegetation Science 11 (5): 739-768.

Westhoff, V. \& van der Maarel, E. 1973: The BraunBlanquet Approach. In: Whittaker, R.H. (ed.): Ordination and Classification of Communities. 2nd edition, W. Junk. Publishers, The Hague, pp. 617-726.

Wraber, M. 1969: Pflanzengeographische Stellung und Gliederung Sloweniens. Vegetatio 17 (1-6): 176-199.

Zelnik, I. 2003: Phytocoenologic description of moist meadows of the south-eastern Slovenia. M.Sc. thesis, University of Ljubljana, Biotechnical Faculty, 180 pp.

Zelnik, I. 2005: Vegetation of the meadows from the order Molinietalia W.Koch 1926 and contact sites in Slovenia. Doctoral dissertation. University of Ljubljana, Biotechnical Faculty, 196 pp.

Zlinská, J. \& Kubalová, S. 2001: Flóra a vegetácia lokality Gamota na Podunajskej nížine a ochrana jej biodiverzity. Acta Environm. Univ. Comen. 11: $1-120$.

Zupančič, B. 1995: Klimatografija Slovenije. Količina padavin: obdobje 1961-1990. Hidrometeorološki zavod Slovenije, Ljubljana, 366 pp. 


\section{APPENDIX}

List of the relevé localities (from table 1):

1: 0054/3 Radensko polje; 2: 0054/3 Radensko polje; 3: 0158/2 Veliki Podlog; 4: 0158/2 Veliki Podlog; 5: 0058/4 Gržeča vas; 6: 0056/3 Gomila; 7: 0056/3 Gomila; 8: 9462/1 Dragotinci; 9: 9659/1 Cigonca; 10: 9462/1 Dragotinci; 11: 0358/3 Rosalnice; 12: 0358/3 Rosalnice; 13: 0358/3 Rosalnice; 14: 0158/2 Veliki Podlog; 15: 0358/3 Rosalnice; 16: 0158/2 Veliki Podlog; 17: 0158/1 Malence; 18: 0158/2 Veliki Podlog, Raški tali; 19: 0457/3 Veliki Nerajec; 20: 0158/2 Veliki Podlog.

Table 1: Analytical table of the association Triseto-Centaureetum macroptili ass. nova Tabela 1: Analitična tabela asociacije Triseto-Centaureetum macroptili ass. nova

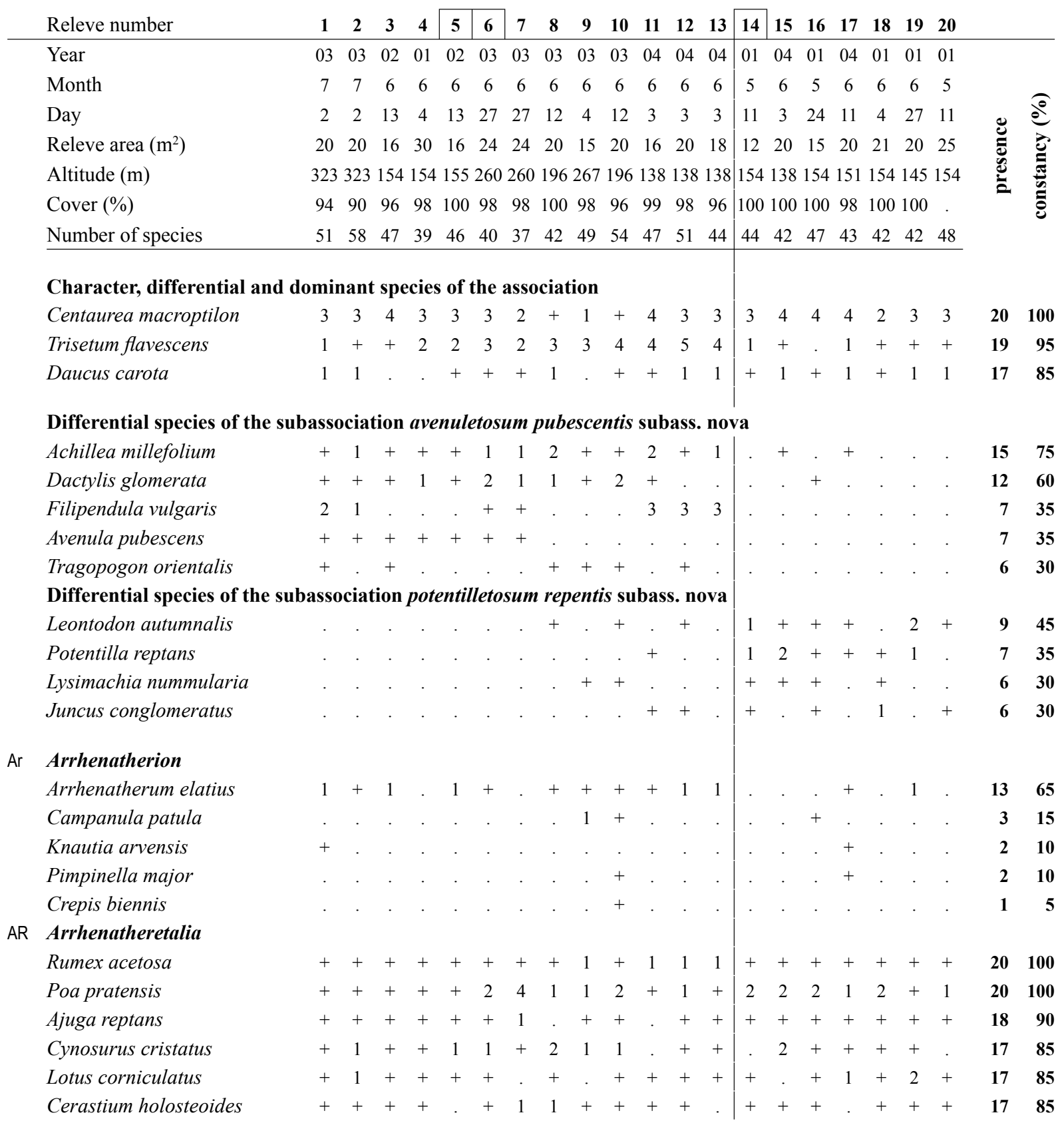




\begin{tabular}{|c|c|c|c|c|c|c|c|c|c|c|c|c|c|c|c|c|c|c|c|c|c|c|c|}
\hline & Releve number & 1 & 2 & 3 & 4 & 5 & 6 & 7 & 8 & 9 & 10 & 11 & 12 & 13 & 14 & 15 & 16 & 17 & 18 & 19 & 20 & & \\
\hline & Trifolium patens & 1 & 1 & + & + & + & 2 & 1 & . & . & + & + & + & . & + & + & + & + & + & 1 & . & 16 & 80 \\
\hline & Prunella vulgaris & + & 1 & + & + & . & . & 1 & . & . & + & 3 & + & 3 & 1 & 1 & + & 1 & 1 & 1 & + & 16 & 80 \\
\hline & Taraxacum officinale agg. & 1 & + & . & . & . & + & + & + & + & + & . & + & . & . & + & + & + & . & + & + & 13 & 65 \\
\hline & Leucanthemum ircutianum & . & . & + & + & + & . & . & . & . & . & . & + & 1 & + & . & + & 3 & 1 & + & 1 & 11 & 55 \\
\hline & Stellaria graminea & . & . & + & . & . & . & . & + & + & + & . & . & . & + & . & + & . & + & . & + & 8 & 40 \\
\hline & Trifolium dubium & . & . & 1 & . & . & . & . & + & . & . & + & + & + & & . & . & + & . & . & + & 7 & 35 \\
\hline & Lolium perenne & . & . & . & . & . & 1 & 2 & + & . & . & + & 2 & 2 & & 2 & . & . & . & . & . & 7 & 35 \\
\hline & Veronica serpyllifolia & . & . & . & . & . & + & . & + & . & . & + & + & + & ${ }^{\circ}$ & + & + & . & . & . & . & 7 & 35 \\
\hline & Trifolium repens & . & . & . & . & . & 1 & 2 & . & . & . & . & + & 1 & $\cdot$ & 1 & . & . & . & + & . & 6 & 30 \\
\hline & Hypochaeris radicata & + & + & . & . & . & . & . & . & + & + & . & . & . & . & . & . & . & . & . & . & 4 & 20 \\
\hline & Rhinanthus minor & . & . & + & + & + & . & . & . & . & . & . & . & . & . & . & . & . & + & . & . & 4 & 20 \\
\hline & Phleum pratense agg. & . & . & . & . & . & . & . & + & . & + & . & . & . & . & . & . & . & . & . & . & 2 & 10 \\
\hline & Bellis perennis & . & . & . & . & . & . & . & + & . & . & . & . & . & . & . & . & . & . & . & . & 1 & 5 \\
\hline MO & Molinietalia & & & & & & & & & & & & & & & & & & & & & & \\
\hline & Lychnis flos-cuculi & . & + & . & + & . & + & + & + & + & + & + & + & + & + & + & + & + & + & + & + & 17 & 85 \\
\hline & Centaurea carniolica & 1 & + & + & + & + & 1 & 1 & 3 & 3 & 1 & . & . & . & + & . & + & + & . & + & 1 & 15 & 75 \\
\hline & Betonica officinalis & 2 & 3 & 2 & 2 & 4 & . & + & . & + & + & 2 & 1 & + & + & . & + & . & + & . & . & 14 & 70 \\
\hline & Carex tomentosa & + & 1 & . & . & . & . & . & . & . & . & + & . & . & + & . & + & + & . & . & . & 6 & 30 \\
\hline & Cardamine pratensis agg. & + & . & . & . & . & . & . & + & . & . & . & . & . & $\theta_{0}$ & + & . & + & . & + & . & 5 & 25 \\
\hline & Deschampsia cespitosa & . & + & . & . & . & . & . & . & + & + & . & . & . & . & . & . & . & . & + & . & 4 & 20 \\
\hline & Selinum carvifolia & + & 1 & . & . & . & . & . & . & + & . & . & . & . & ${ }^{\circ}$ & . & . & . & . & . & . & 3 & 15 \\
\hline & Sanguisorba officinalis & . & . & . & . & . & . & . & + & + & + & . & . & . & . & . & . & . & . & . & . & 3 & 15 \\
\hline & Colchicum autumnale & . & . & . & . & . & . & . & + & . & . & . & . & . & . & + & . & 1 & . & . & . & 3 & 15 \\
\hline & Bromus racemosus & . & . & . & . & . & . & . & . & . & . & . & + & . & . & . & . & . & + & + & . & 3 & 15 \\
\hline & Molinia caerulea & + & + & . & . & . & . & . & . & . & . & . & . & . & . & . & . & . & . & . & . & 2 & 10 \\
\hline & Myosotis scorpioides & . & . & + & + & . & . & . & . & . & . & . & . & . & . & . & . & . & . & . & . & 2 & 10 \\
\hline & Ophioglossum vulgatum & . & . & . & + & . & . & . & . & . & . & . & . & . & . & . & . & . & . & . & + & 2 & 10 \\
\hline & Vicia tetrasperma & . & . & . & . & . & . & . & + & . & + & . & . & . & . & . & . & . & . & . & . & 2 & 10 \\
\hline & Succisella inflexa & . & . & . & . & . & . & . & . & . & . & . & . & . & + & . & . & . & . & + & . & 2 & 10 \\
\hline & Filipendula ulmaria & . & + & . & . & . & . & . & . & . & . & . & . & . & . & . & . & . & . & . & . & 1 & 5 \\
\hline & Linum catharticum & . & + & . & . & . & . & . & . & . & . & . & . & . & . & . & . & . & . & . & . & 1 & 5 \\
\hline & Succisa pratensis & . & + & . & . & . & . & . & . & . & . & . & . & . & . & . & . & . & . & . & . & 1 & 5 \\
\hline & Gentiana pneumonanthe & . & + & . & . & . & . & . & . & . & . & . & . & . & . & . & . & . & . & . & . & 1 & 5 \\
\hline & Viola elatior & . & . & . & . & + & . & . & . & . & . & . & . & . & . & . & . & . & . & . & . & 1 & 5 \\
\hline & Hypericum tetrapterum & . & . & . & . & . & . & . & . & 2 & . & . & . & . & . & . & . & . & . & . & . & 1 & 5 \\
\hline & Lysimachia vulgaris & . & . & . & . & . & . & . & . & . & + & . & . & . & . & . & . & . & . & . & . & 1 & 5 \\
\hline & Crepis paludosa & . & . & . & . & . & . & . & . & . & . & . & . & . & . & . & . & + & . & . & . & 1 & 5 \\
\hline & Lythrum salicaria & . & . & . & . & . & . & . & . & . & . & . & . & . & . & . & . & . & + & . & . & 1 & 5 \\
\hline & Symphytum officinale & . & . & . & . & . & . & . & . & . & . & + & . & . & . & . & . & . & . & . & . & 1 & 5 \\
\hline MA & Molinio-Arrhenatheretea & & & & & & & & & & & & & & & & & & & & & & \\
\hline & Holcus lanatus & 3 & 4 & 2 & 3 & 3 & 3 & 3 & 3 & 4 & 4 & 2 & 2 & 3 & 4 & 2 & 4 & + & 3 & 3 & 1 & 20 & 100 \\
\hline & Ranunculus acris & 1 & 2 & + & + & + & 1 & + & 1 & + & + & 2 & 2 & 2 & 1 & 2 & 1 & 1 & 2 & 1 & 2 & 20 & 100 \\
\hline & Festuca pratensis & + & 1 & + & 1 & + & 1 & 1 & + & 1 & 2 & 2 & 1 & + & 1 & + & 2 & 2 & 2 & 2 & + & 20 & 100 \\
\hline & Plantago lanceolata & + & + & 1 & 1 & 1 & 2 & 1 & 2 & + & + & + & + & + & + & . & + & + & + & + & + & 19 & 95 \\
\hline & Festuca rubra agg. & 2 & + & 2 & 1 & 1 & 1 & 1 & + & 1 & 1 & 1 & . & + & 1 & + & 1 & 2 & . & 1 & 3 & 18 & 90 \\
\hline & Anthoxanthum odoratum & 1 & 1 & 2 & + & 3 & 2 & 2 & . & 3 & 1 & . & + & 1 & 2 & + & 1 & + & 3 & + & 2 & 18 & 90 \\
\hline & Lathyrus pratensis & + & + & 1 & + & + & + & + & + & . & + & + & + & + & + & . & + & + & . & . & + & 16 & 80 \\
\hline & Trifolium pratense & . & + & + & + & + & . & . & . & + & + & 1 & 1 & 3 & + & 1 & + & 1 & + & + & + & 16 & 80 \\
\hline & Leontodon hastilis & 3 & + & $\cdot$ & . & . & 1 & 1 & . & + & + & + & 3 & + & + & 1 & . & 2 & . & 2 & 2 & 14 & 70 \\
\hline & Centaurea jacea & 1 & 2 & + & . & + & + & + & + & . & + & . & + & + & & + & . & 1 & . & + & + & 14 & 70 \\
\hline
\end{tabular}




\begin{tabular}{|c|c|c|c|c|c|c|c|c|c|c|c|c|c|c|c|c|c|c|c|c|c|c|}
\hline Releve number & 1 & 2 & 3 & 4 & 5 & 6 & 7 & 8 & 9 & 10 & 11 & 12 & 13 & 14 & 15 & 16 & 17 & 18 & 19 & 20 & & \\
\hline Galium mollugo agg. & . & + & 1 & + & & 1 & + & 1 & + & 2 & + & 1 & $\cdot$ & & . & + & 2 & + & + & $\cdot$ & 14 & 70 \\
\hline Carex hirta & + & 1 & + & . & 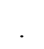 & . & . & + & . & . & + & + & 2 & + & 2 & . & . & + & . & + & 11 & 55 \\
\hline Leontodon hispidus & + & . & . & . & . & + & + & + & . & + & . & . & + & + & + & . & . & + & + & + & 11 & 55 \\
\hline Ranunculus repens & . & . & . & . & . & . & . & . & + & + & + & . & . & + & 1 & 1 & . & 1 & . & . & 7 & 35 \\
\hline Alopecurus pratensis & . & + & . & . & . & . & . & 2 & 1 & 1 & . & . & . & . & 3 & . & + & . & . & . & 6 & 30 \\
\hline Poa trivialis & . & . & . & . & . & . & + & . & + & . & + & . & . & . & 1 & . & . & . & + & + & 6 & 30 \\
\hline Rumex crispus & . & . & . & . & . & . & + & . & . & . & . & + & + & + & + & . & + & . & . & . & 6 & 30 \\
\hline Leucanthemum praecox & . & . & . & . & . & . & . & . & + & + & . & . & . & 2 & . & 1 & . & + & . & . & 5 & 25 \\
\hline Moenchia mantica & . & . & . & . & . & . & . & . & . & . & 3 & 1 & 3 & & 2 & . & . & . & . & . & 4 & 20 \\
\hline Agrostis stolonifera agg. & . & . & . & . & . & 1 & . & . & + & . & . & . & . & . & . & . & . & . & 1 & . & 3 & 15 \\
\hline Vicia cracca & . & . & . & . & . & . & . & . & 1 & + & . & . & . & . & . & . & . & . & . & . & 2 & 10 \\
\hline Lolium multiflorum & . & . & . & . & . & . & . & + & . & . & . & . & . & . & . & . & . & . & . & . & 1 & 5 \\
\hline Rumex obtusifolius & . & . & . & . & . & . & . & + & . & . & . & . & . & . & . & . & . & . & . & . & 1 & 5 \\
\hline Plantago major & . & . & . & . & . & . & . & . & . & . & . & + & . & . & . & . & . & . & . & . & 1 & 5 \\
\hline Epilobium tetragonum & . & . & . & . & . & . & . & . & . & . & . & + & . & . & . & . & . & . & . & . & 1 & 5 \\
\hline \multicolumn{23}{|l|}{ Phragmiti-Magnocaricetea } \\
\hline Carex vulpina & . & . & . & . & 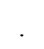 & . & . & . & . & + & . & . & . & . & + & . & . & + & . & . & 3 & 15 \\
\hline Galium palustre & . & . & . & . & . & . & . & . & . & . & . & . & . & + & . & + & . & + & . & . & 3 & 15 \\
\hline Carex acuta & . & . & . & . & . & . & . & + & . & . & . & . & . & . & . & . & . & . & + & . & 2 & 10 \\
\hline Lycopus europaeus & . & . & . & . & . & . & . & . & . & . & . & . & . & + & . & . & . & . & . & . & 1 & 5 \\
\hline \multicolumn{23}{|l|}{ Scheuchzerio-Caricetea fuscae } \\
\hline Agrostis canina & + & + & + & . & + & . & + & . & + & . & . & . & . & + & . & . & . & . & + & + & 9 & 45 \\
\hline Carex panicea & . & + & . & . & + & . & . & . & . & . & . & . & . & . & . & . & + & . & 1 & . & 4 & 20 \\
\hline Carex hostiana & . & + & . & . & . & . & . & . & . & . & . & . & . & . & . & . & . & . & . & . & 1 & 5 \\
\hline Carex flava & . & + & . & . & . & . & . & . & . & . & . & . & . & . & . & . & . & . & . & . & 1 & 5 \\
\hline Taraxacum palustre & . & . & . & . & . & . & . & . & . & . & . & . & . & . & . & . & . & . & + & . & 1 & 5 \\
\hline \multicolumn{23}{|l|}{ Festuco-Brometea } \\
\hline Galium verum & 1 & 2 & 1 & 1 & 2 & 1 & . & 2 & 3 & . & 2 & 2 & 2 & + & + & 1 & 2 & + & . & + & 17 & 85 \\
\hline Briza media & 2 & 1 & 1 & 1 & + & . & . & . & . & . & + & . & + & . & + & + & . & + & 4 & + & 12 & 60 \\
\hline Carex flacca & + & 1 & . & . & . & . & . & . & . & . & . & . & + & . & . & . & . & . & . & . & 3 & 15 \\
\hline Allium carinatum & + & + & . & . & . & . & . & . & . & . & . & . & . & . & . & . & . & . & . & . & 2 & 10 \\
\hline Campanula glomerata & + & + & . & . & . & . & . & . & . & . & . & . & . & . & . & . & . & . & . & . & 2 & 10 \\
\hline Ranunculus bulbosus & . & . & . & . & . & . & . & . & . & . & . & + & 1 & . & . & . & . & . & . & . & 2 & 10 \\
\hline Helianthemum nummularium & . & . & . & . & 1 & . & . & . & . & . & . & . & . & . & . & . & . & . & . & . & 1 & 5 \\
\hline Trifolium ochroleucon & . & . & . & . & + & . & . & . & . & . & . & . & . & . & . & . & . & . & . & . & 1 & 5 \\
\hline Brachypodium pinnatum agg. & . & . & . & . & + & . & . & . & . & . & . & . & . & . & . & . & . & . & . & . & 1 & 5 \\
\hline \multicolumn{23}{|l|}{ Calluno-Ulicetea } \\
\hline Carex pallescens & + & + & + & + & 1 & . & . & . & + & . & + & . & + & + & . & + & . & + & . & + & 12 & 60 \\
\hline Luzula campestris agg. & + & + & + & + & + & . & . & . & + & . & + & + & 1 & + & . & + & . & . & . & 1 & 12 & 60 \\
\hline Potentilla erecta & + & + & 1 & 1 & 1 & . & . & . & . & . & . & . & . & + & . & + & . & + & + & + & 10 & 50 \\
\hline Festuca filiformis & 1 & . & + & . & 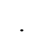 & 1 & . & . & + & . & + & . & . & 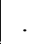 & . & . & . & . & . & 1 & 6 & 30 \\
\hline Danthonia decumbens & . & + & + & . & + & . & . & & . & . & . & . & . & 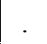 & . & . & . & . & . & + & 4 & 20 \\
\hline Thymus pulegioides & . & . & + & + & 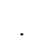 & . & . & & . & . & . & . & . & 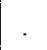 & . & . & . & . & . & + & 3 & 15 \\
\hline Carex leporina & . & . & . & + & 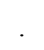 & . & . & & + & . & . & . & . & . & . & . & . & . & . & + & 3 & 15 \\
\hline Viola canina & + & + & . & . & . & . & . & & . & . & . & . & . & . & . & . & . & . & . & . & 2 & 10 \\
\hline Hieracium umbellatum & . & + & . & . & + & . & . & & . & . & . & . & . & . & . & . & . & . & . & . & 2 & 10 \\
\hline Nardus stricta & . & . & + & . & + & . & . & . & . & . & . & . & . & . & . & . & . & . & . & . & 2 & 10 \\
\hline
\end{tabular}


\begin{tabular}{lllll|l|l|llllllll|l|llllll|l}
\cline { 5 - 8 } Releve number & 1 & 2 & 3 & 4 & 5 & 6 & 7 & 8 & 9 & 10 & 11 & 12 & 13 & 14 & 15 & 16 & 17 & 18 & 19 & 20
\end{tabular}

Hieracium lactucella

Polygala vulgaris

S Late-successional species

Veronica chamaedrys

Cruciata glabra

Carex brizoides

Anemone nemorosa

Agrimonia eupatoria

Quercus robur

Clinopodium vulgare

Knautia drymeia

Rosa canina

Carex elongata

Myosotis sylvatica

Ornithogalum pyrenaicum

Alnus glutinosa

Euonymus europaeus

Ulmus sp.

o Other species

Erigeron annuus

Calamagrostis epigejos

Carex spicata

Equisetum arvense

Medicago sativa

Euphorbia helioscopia

Dianthus barbatus

Centaurea sp.

Vicia hirsuta

Picris hieracioides

Cichorium intybus

Medicago sativa agg.

Elymus repens

Bromus hordeaceus

Myosotis arvensis

Cerastium glomeratum

Conyza canadensis

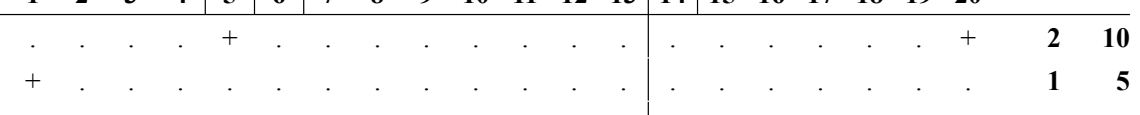

$\begin{array}{ll}13 & 65\end{array}$

$5 \quad 25$

420

420

420

210

$\begin{array}{ll}2 & 10\end{array}$

210

210

15

15

15

15

15

15 